\title{
STUDENT PRESENTATIONS UPGRADES THROUGH USE OF LANGUAGE LEARNING STRATEGIES
}

\author{
Iis Lisnawati ${ }^{1)}$, Yuyun Yuniawati ${ }^{2)}$ Titin Kusmini ${ }^{3)}$ \\ 1) Siliwangi University, West Java, Indonesia \\ E-mail: is.lisnawati@yahoo.co.id
}

\begin{abstract}
This research is experimental testing of Language Learning Strategies to improve student presentation at the Indonesian Department of Education, University of Siliwangi, Tasikmalaya. Learning stage presentations using Language Learning Strategies are as follows. (1) preparation, (2) presentation, (3) practice, (4) evaluation, (5) expansion activities. In each stage been LLS is eclectic in accordance with the needs of learning, good learning objectives, material characteristics, and the characteristics of the students. There is a significant difference between the mean score of the pretest to posttest mean score in the experimental class and there is a significant difference between the mean score of posttest in the experimental class with a mean score of posttest in control classes. This proves that effective language learning strategies to improve student presentation.
\end{abstract}

Keywords: presentation, language learning strategies

\section{INTRODUCTION}

Functionality presentation for the student is felt. The presentation is required in the academic world, organization, recruitment (Chivers \& Shoolbred, 2007) or the world of work (Business The ultimate Resource (2007) \& Kapterev (2011)). According to Zivkovic (2014) oral presentation enabling students to function successfully in the future professional surrounding, and preparing them for further academic Reviews their possible. For students of Language and Literature Education Department of Indonesia as a prospective teacher, they not only demanded to presentations in these things but also required to be able to transfer and presentation capabilities to teach to their students later. Therefore, prior to their transfer and presentation capabilities to teach to their students, the students themselves must be capable of presenting. This, of course, requires training. Syihabuddin (2009) argues speaking skills, learned, practiced, and built to students varies, ranging from the simple to the skills of complex skills such as presenting a paper in a scientific forum.

Although the presentation is very important for the ability of students, the phenomenon, and reality of the presentation capabilities of students facing today is not yet meet expectations. Cause three are not maximal students in the presentation were the difficulty of students in developing the content of the conversation and use the Indonesian language properly and difficulties students overcome anxiety and nervousness when speaking in front of crowds.

The above is actually a consequence of the nature of the presentation as a kind of talking itself. Talking is a complex activity that requires the use of a number of different abilities simultaneously (Harris, 1969). According to Thornbury (2005), there are a number of factors that determine easy or difficult it is to talk, that is a factor of cognitive, affective factors and performance factors. Brown (2001) argues that one of the main obstacles to be overcome learners in learning to talk is the anxiety that causes learner throws things wrong or incomprehensible. This suggests that the language is a psychological activity (Greene, 2000). In addition, Piaget in Slavin (2005) argues that knowledge of social devicelanguage, values, laws, morality, and a system of symbols (such as reading and math) - can only be learned in interaction with others so that by VanPatten (1996) were considered in the study not only the cognitive mechanisms, but also the social dimension will also build affective learner.

The above suggests that the presentation of learning strategy selected and used the strategy should provide an opportunity for students to develop cognitive, affective, and social dimensions. The strategy provides an opportunity for students, as noted above are Language Learning Strategies is hereinafter abbreviated as LLS.

Strategies are especially important for language learning Because they are tools for active, self-directed involvement, the which is essential for developing communicative competence. Appropriate language learning strategies result in 
improved proficiency and greater self -confidence .. Learning strategies are specific actions taken by the learner to Make Learning Easier, faster, 'more enjoyable, more self-directed, more effective, and more transferable to new situations (Oxford, 1990). LLS is specific actions, behaviors, tactics, or techniques that facilitate the attainment of the target language by the learner (Muho \& Kurani, 2011).

LLS is composed of two types, namely direct strategy 'direct strategy' and the indirect strategy 'indirect strategy'. Direct strategies include the strategy of memory (used to store and retrieve aspects of the target language), cognitive strategies (used to use the language and to understand how it works), and compensation strategies (used to use the language even though there are gaps in knowledge). Indirect strategies include metacognitive strategies (used for planning, organizing and evaluating learning), affective strategy (used to approach the task positively), and social strategies (used to collaborate with others to get help) (Oxford, 1990).

LLS appears to be one of the most important variables that affect performance in a second language. Therefore, teachers need to be more aware of the learner will LLS through proper training. Teachers can help their learners by designing instruction that meets the needs of individuals with different style preferences and teaches learners how to improve their LLS (Muho \& Kurani, 2011).

Learning stage presentations using Language Learning Strategy is as follows. (1) preparation, (2) presentation, (3) practice, (4) evaluation, (5) expansion activities (O'Malley \& Chamot, 1990). This is the stage of operational use of LLS known as CALLA (Cognitive Academic Language Learning Approach) developed O'Malley and Chamot, 1990).

In each stage been LLS is eclectic in accordance with the needs of learning, good learning objectives, material characteristics, and the characteristics of the students. LLS LLS used was developed by Oxford (1990), which is considered a more detailed and comprehensive (Lee (2010), Zare (2012)) with the rare step of speaking developed Cohen (1996).

\section{METHOD}

This study used an experimental method. In this case, the use of LLS conducted trials to improve student presentation. Fraenkel, et.al (2012) found an experimental study is unique in two things are very important, which is the only study that directly trying to influence specific variables, and when applied correctly, it is the best kind to test hypotheses about the causes -and- effect relationship.

\section{RESULT AND DISCUSSION}

Based on the data obtained is known there are differences in pretest mean score (71.88) to the posttest mean score (84.47) in the experimental class, amounting to 12.59. In addition, note also that there are differences between the mean score of posttest in experimental class (84.47) and the mean score of posttest control group (77.18), amounting to 7.29.
Based on statistical calculations $t$ pair test is known that there are significant differences between the mean score of pretest to post-test mean score with a mean score of post-test in the experimental class and there is a significant difference between the mean score of post-test in the experimental class with the average post-test score in grade in the class control. This shows that the use of LLS effectively used to enhance the presentation skills of students.

The significant difference between the mean score pretest and the average score of post contained in each component of the indicator of the ability of a presentation that covers the content of the conversation (focus, breadth, depth), aspects of the structure of the content (payload/content of contents: introduction, contents, cover; systematics and the proportion of the grain), aspects of language structure (choice of words: clarity, inclusiveness, and accuracy; sentence: communiactiveness, variation, truth), as well as aspects of performance (vocalization: tone, intonation and pauses, pronunciation; the expression: eye contact, gestures, gestures).

The effectiveness of the use of LLS due to the measures were undertaken in the learning gives students the opportunity to develop cognitive, metacognitive, affective, and social students. The learning process by using LLS presentation was preceded by pre teaching-learning. Pre teaching-learning done for LLS is required to apply an understanding of language learning strategies, objectives LLS use by students so that with this understanding, students are expected to carry out in an optimal learning. This is in line with the opinions Trianto (2010) that teaching-learning strategies, there are several things that must be considered, namely (1) tell the students that to them will be taught strategies for learning so that their attention is focused, (2) showed a positive association use learning strategies to learning achievement and notify the need for extra thought to produce high performance, (3) explain and demonstrate strategies that will be taught, (4) to explain when and why a learning strategy use.

The use of LLS in learning activities presentation has five stages, namely: (1) preparation, (2) presentation, (3) practice, (4) evaluation, (5) expansion activities (O'Malley \& Chamot, 1990).

The preparation phase is done at the beginning of the learning activities. At this stage, enthusiastic students are seen as a conditioning class. Students answered greetings, greeting afternoon professors and lecturers spirit greeting in unison. In apperception students connect the material to be studied with its knowledge and experience (metacognitive strategies). When a student does not respond, reminding professors and fishing with some questions and ask and answer with students about the benefits of any activity undertaken. It aims to make students aware of every activity and its benefits. That is, students are expected to do all of the activities and not solely for the instruction of lecturers, but all the activities are done on awareness of students even if initially activity was done on the initiative of the lecturer. It was compatible with the intended use as proposed by Shmais LLS (2003) that the main purpose of the LLS is to enable learners to become more aware of learning strategies they use and to help them become more responsible for their own purposes. Those goals can only 
be achieved if learners are trained in the use of strategies so that they become more independent and effective. Chamot (2004) suggested that Learning strategies are the conscious thoughts and actions that learners take in order to Achieve a learning goal.

At this stage of student presentations in groups (social strategy: working with others, ask questions to clarify or correct) analyze impressions (model group presentations) (cognitive strategy: analyzing the expression) with the guidance given faculty, linking and comparing it with the knowledge or experience of students (metacognitive strategies), record (cognitive strategies) analysis results, discuss findings (social strategy: ask), and reasoning to infer (cognitive strategies).

At this stage, all of the students in the group observe the impressions reminded by lecturers in order to connect with the knowledge and experience they have. After completion notice impressions of students answering questions with answers recorded individually and their answers are discussed in their respective groups to conclude.

When discussing class students who speak from each group to report or respond to the results of discussions in turns so that the conversation is not dominated by a particular student. That is, students are quite active and participatory. This is possible because each student already has the answers to their own findings or results of the group discussions.

Efforts to raise the awareness of students will LLS on the presentation made by praise on students argued and feedback. This is in line with the opinions Trianto (2010) that in use learning strategies should do the following things.

1) provide reinforcement to students who use learning strategies

2) to provide feedback when testing materials with a certain strategy.

At this stage of practice, students practice presenting in the classroom twice. Practice presentations first performed in the respective groups. The second presentation practices carried out in front of the class. Stage practice includes the step prior to presentation (presentation preparation stage) and stage presentation (presentation execution stage).

Practice is not only done in the classroom but also do outside the classroom with the same guidelines with practice in the classroom. To ensure that students practice outside of class, students must submit a recording of the practice.

At the stage before the presentation, the preparatory stage student presentations informal discussion in the group (social strategy: working together with friends, ask clarifying or correcting) on the topic (Cognitive Strategies: using a variety of sources, recorded information), making a framework for discussion, develop a framework for discussion (strategy metacognitive: connect it with prior knowledge, organize the content of the conversation). To do all of these activities linking students with knowledge and experience related (metacognitive strategies), using a variety of sources (cognitive strategies) by utilizing already available materials, handouts, laptops, mobile phones, and the Internet. (Lecturer reminded that using mobile phones and the internet to complete the task and responsibility of the student to ask the reason for using a variety of sources).

The implementation stage includes the presentation before speaking, speaking, and after speaking. The presentation used at the stage before speaking is relaxed, making a positive statement (affective strategies). At this stage, there are students who took the initiative themselves to relax in a manner of his own choosing not drilled. This shows that the students have their own consciousness to choose strategies appropriate to their needs. This will be the foundation that LLS encourage students to become independent. As noted Querol (2010) that the strategy should offer opportunities for students to become independent learners.

At the current stage, the students spoke no attempt to speak without notes for distraction, but there is also a record in the form of an outline of the material to be conveyed (cognitive strategy). Monitor yourself (metacognitive strategy) while talking difficult to observe because of the form of abstract behavior. It is actually an LLS characteristic itself as expressed Oxford (1990) that LLS is not always easily observed. Cooperate with other learners to achieve the learning objectives is a strategy that can be observed, but the act of making a mental association, memory strategies cannot be observed.

The above drawbacks can be overcome to think aloud procedures (Oxford, 1990), namely the form of an oral report about the thought processes that do learners when doing an activity of language learning.

After speaking students were trained to assess the communications ability and its use of LLS (metacognitive strategy: to evaluate its own). In this case a class discussion, students express a mutual assessment of her abilities, other students respond or comment. This is in line with the opinions Trianto (2010) that the use of LLS teachers should evaluate learning strategies and encourage students to do the evaluation.

In addition to assessing themselves, students also gave tribute to him according to his ability (affective strategy: respect yourself). The assortment of student expression in respecting themselves and discuss with friends about the feelings he felt when presenting (affective strategies: discuss feelings with the other person). According to them the feeling they are the same, cannot feel good presentation, the most associated with emotional stability. It can be their motivation to practice until actually capable presenting well.

To assess their consistency in using LLS students must fill out a checklist that has been provided, lecturers. It actually will help their consciousness in every activity.

In the expansion phase is discussed about the benefits of learning activities are carried out, both with regard to LLS and learning materials in a broader scope. In this discussion the class and the teacher. At this stage, the students show passion or motivation and persistence in answering questions related to the use of lecturers LLS, the contents of the conversation, performance, and language.

From the series of activities of faculty and students over the use of LLS in learning, presentations can be stated that the lecturer role as initiator, motivator, facilitator, guide, 
consultant, coordinator. This is in line with the opinion of Oxford (1990) that teachers in the use of LLS act as facilitators, guides, consultants, advisors, coordinators, speakers, expert diagnostic and communicators.

LLS position the student as a subject of study. Students perform information processing activities. When students connect the material being studied with previous knowledge in apperception or analyze impressions presentation, in essence, they're digging up information that has been stored in their memory. When students observe impressions, notes, discuss in essence they are obtaining the information, store, and recall when they express opinions. Similarly, when they practiced, in essence, they must disclose return information that they have acquired and their store in the memory. In fact, the information was empowered when they talk through the activities of monitoring the conversation. Thus, knowledge relating to the contents of the conversation, language rules, they have become functional. In this connection, O'Malley and Chamot (1990) suggested learning strategies are special ways of processing information that Enhance comprehension, learning, or retention of the information. Oxford (1990) argue that language learning strategies are operations employed by the learner to aid the acquisition, storage, retrieval, and use of information. Rebecca Ehrman and Oxford (2008) states that the Strategies are conscious steps or behaviors Often used by language learners to Enhance the acquisition, storage, retention, recall, and use of new information.

LLS not only enable cognitive students but also hone affective students through activities to relax, make positive statements, self-respect, to discuss feelings with others and interact socially in the use of language with other students through the activities asked to clarify or verify, asking to correct and cooperate with friends.

Of activities before a student can activate linguistic competence, sociolinguistic competence, discourse competence, and competence strategies. As noted Oxford (1990) that the essence of LLS who are learning involves many aspects of the learner, not just cognitive. LLS is not confined to cognitive function. The strategy also includes metacognitive functions (such as planning, evaluation, and regulate one's own learning), affective, social, and other functions. LLS contribute to achieving the main goal of communicative competence.

An explanation or asked questions about the benefits of LLS for learning can make students have confidence in doing the activities that positively affect the achievement of learning objectives or student achievement and independence. In this connection, Oxford (1990) suggested that the LLS made more independent learners. Trianto (2010) argues that the teachinglearning strategies based on the proposition that student success largely depends on the skills for independent learning. It is in line with current educational demands. As noted Azrien, et al. (2011) that in the context of today's world, education is not only focused on the acquisition of knowledge and get good grades in exams, but also on improving the learner to direct the learning potential and ability to cope with challenges of their own learning environment. Learners are responsible for their own learning. They are no longer seen as passive individuals as recipients of information, they are also actively engaged in learning activities that facilitate the formation of the relationship between information and knowledge.

The above was in tune with the demands of education in Indonesia. As indicated on the Law of the Republic of Indonesia Number 20 Year 2003 on National Education System that national education serves to develop the ability and character development and civilization of the nation's dignity in the context of the intellectual life of the nation, is aimed at developing students' potentials in order to become a man of faith and fear God Almighty, noble, healthy, knowledgeable, skilled, creative, independent, and become citizens of a democratic and accountable.

Based on the above it can be stated that the learning presentations using above description also suggests also that the interaction in the learning of the presentation by using LLS is multidirectional interaction, namely the interaction of faculty and students, student interaction with the students, even the interaction between students with instructional materials. Thus, the use of LLS in learning presentation desired direction of the interaction of adult education, namely interaction multidirectional. As noted Djamarah (2005) that the communication as a transaction (multidirectional: the interaction between teachers and students and among students with students) are considered in accordance with the concept of learning to CBSA as desired by those skilled in modern education. In this connection, Abidin (2014) suggested that the learning success will greatly depend on the significance of interaction multidirectional or educational interaction, that interaction serves to develop various potentials of learners in order to develop the knowledge itself. These interactions should further inspire, fun, challenge, motivate, provide enough space for innovation, creativity, and independence according to their talents, interests, and physical and psychological development of learners. This is in accordance with the mandated Regulation of the Minister of Education and Culture of the Republic of Indonesia Number 49 The year 2014 on National Education Standards Article 13 that the implementation of the learning process takes place in the form of interaction between faculty, students, and learning resources in a particular learning environment.

Another thing that can be concluded from the above description is that in learning presentation by using LLS lecturers in addition to planning a conscious components of learning already established and LLS must be planned and carried out consciously anyway so all LLS is done consciously also by students in order to achieve learning objectives as part of the purpose of education. It is actually in accordance with the nature of education itself. As stated in Law No. 20 of 2003 that education is a conscious and deliberate effort to create an atmosphere of learning and the learning process so that learners are actively developing the potential for him to have the spiritual power of religion, selfcontrol, personality, intelligence, noble character, and skills needed him, society, nation, and country.

The effectiveness of the use of LLS in learning has been shown in previous studies, namely increasing the ability to 
talk by using LLS (Cohen, et al, 1996), increased ability to read English texts using cognitive strategies and metacognitive (Hamdan, et al), memory strategies more intensively in the first language learning (Yang \& Wang), increase English proficiency by using metacognitive strategies (Juyeon, Heinz, \& Michael, 2016).

\section{CONCLUSION}

Based on the data analysis can be concluded that effective language learning strategies used to improve student presentation.

The learning process is a presentation by using LLS is a learning process based on the strategy in the form of behavior or specific activities that use learners in learning activities that include cognitive strategies, metacognitive strategies, strategies affective, and social strategies so as to engage and develop the whole realm of psychology students, both cognitive , affective, and psychomotor implemented through individual action or through social interaction.

The learning process by using LLS presentation is done in five stages, namely: (1) preparation, (2) the stage of presentation, (3) the stage of practice, (4) the evaluation phase, (5) the expansion phase. At each stage of use LLS in accordance with the purpose of learning, learning materials, and the students' needs.

The learning process by using LLS presentation faculty position as an initiator, motivator, facilitator, guide, consultant, and coordinator, while the learner as a subject of study which enables the entire realm of psychological and social dimensions.

The learning process is a presentation by using LLS multidirectional learning process. Interaction is not only the interaction between faculty and students but also students with student interaction and student interaction with the learning materials.

Research use of LLS in learning presentation was done without considering the factors that influence the LLS, which is a factor of consciousness, learning phase, types of tasks, objectives that were defined teacher, age, gender, nationality/ethnicity, learning styles common, personality traits, level of motivation, and purpose of language learning. Therefore, future studies should consider these factors.

\section{REFERENCES}

Abidin, Y. (2014). Pembelajaran Bahasa Berbasis Pendidikan Karakter Bandung: Refika Aditama.

Azrien, M. Adnan, M., \& Mohamad, S. (2011). Language learning strategies and self-efficacy beliefs in Arabic language learning: a Malaysian context. AJTLHE Vol. 3, No. 2, July 2011, 48-59. ISSN: 1985-5826. [On line]. Available: http://www.ukm.my/ the / pdf / 78-En AJTLHE Mohamad Azrien KB.pdf UM.

Brown, HD (2001). Teaching by Principles: An Interaction Approach to Langauge Pedagogy. San Francisco: Longman.

Business The Ultimate Resource. (2007). Give Great Presentations: How to Speak Confidently and Make Your Point. London: A \& C Black Publishers Ltd.

Chamot, AU (2004). Issues in Language Learning and Teaching Strategy Research. Electronic Journal of Foreign Language Teaching, 2004 Vol. 1, No. 1, pp. 14-26. [On line]. Available: http://e-flt.nus.edu.sg/
Chivers, B., \& Shoolbred, M. (2007). A Student's Guide to Presentations: Making Your Presentation Count. California: SAGE Publications Ltd.

Cohen, AD, et.al. (1996). The Impact of Strategies-Based Instruction on Speaking a Foreign Language. [On line]. Available: http: // carla. acad.umn.edu/ resources / working-papers / documents / ImpactofStrategiesBased Instruction. pdf.

Djamarah, SB (2005). Guru dan Anak Didik dalam Interaksi Edukatif: Suatu Pendekatan Teoretis Psikologis. Jakarta: PT Rineka Reserved.

Ehrman, M., Madeline and Rebecca Oxford. (2008). "Adult Language Learning Styles and Strategies in an Intensive Training Setting". Foreign Service Institute College of Education $1501 \mathrm{~S}$. University of Alabama Randolph Street Arlington, VA 22204 Tuscaloosa, AL. [On line]. Available: HTTP: // ww. academia.edu/2344095/Adult_language_learning_styles__ and strategies_in_an_intensive_training_setting

Fraenkel, et.al. (2012). How to Design and Evaluate Research in Education. New York: The McGraw-Hill Companies.

Greene, J. (2000). Language Understanding a Cognitive Approach Philadelphia: Open University Press.

Hamdan, AR, et.al. The Cognitive and metacognition Reading Strategies of the Foundation Course Students in Teacher Education Institute in Malaysia. European Journal of Social Sciences. Volume: 13 Page: 133144. [Online] Available: http://lib.education.vnu.edu.vn:8121/bitstream/123456789/ 4558/1 / TeacherEducation 10963.pdf.

Harris, DV (1969). Testing as a Second Language. USA: McGraw-Hill, Inc Juyeon, L., Heinz, and Michael. English Language Learning Strategies Reported by Advanced Language Learners. Journal of International Education Research. v12 n2 p67-76 2016 [Online]. Available: http://files.eric.ed.gov/

Kapterev, A. (2011). Presentation Secrets: Do What You Never Thought Possible with Your Presentations. Indiana: John Wiley \& Sons, Inc.

Lee, CK (2010). "An overview of language learning strategies". ARECLS 2010, Vol.7,132-152. [On line]. Available: http: // research .ncl.ac.uk / ARECLS / volume7 / lee_vol7.pdf

Muho, A., \& Kurani, A. (2011). Learning Strategies in Second Language Learning and Teaching. ISSN 2039-2117. Mediterranean Journal of Social Sciences Vol. 2, No. 3, September 2011. pp 174-178. [On line]. Available: http://www.mcser.org/images/ stories / 2_journal / mjssso203 / september 2011 /17.anitamuho.pdf.

O'Malley, IM, \& Chamot, AU (1990). Learning Strategies in Second Language Acquisition. New York: Cambridge University Press.

Querol., MB (2010). College students' use of affective and social language learning strategies: a classroom-based research. ESL Philippine Journal, Vol. 5, July 2010. [Online]. Available: http://www. philippineESL-journal. com/V5_A8.pdf.

Oxford, RL (1990). Language Learning Strategies: What Every Teacher Should Know. New York: Newbury House Publishers.

Peraturan Menteri Pendidikan dan Kebudayaan Republik Indonesia Nomor 49 Tahun 2014 tentang Standar Nasional Pendidikan.

Shmais, WA (2003). Language Learning Strategy Use in Palestine. The Electronic Journal for English as a Second Language. Volume 7 No. 7. [Online]. Available: http://www.tesl-ej.org/wordpress/ issues/volume7/ ej26/ ej26a3/.pp 1-13.

Slavin, RE (2005). Cooperative Learning: Teori, Riset, dan Praktik (Diterjemahkan oleh Narulita Yusron). Bandung: Nusa Media.

Syihabuddin. (2009). Evaluasi Pengajaran Bahasa Indonesia. Bandung: Program Studi Pendidikan Bahasa Indonesia, Sekolah Pascasarjana UPI Bandung.

Thornbury, S. (2005). How to Teach Speaking. New York: Longman.

Trianto. (2010). Mendesain Pembelajaran Inovatif-Progresif. Jakarta: Kencana Prenada Media Group.

Undang-Undang Republik Indonesia Nomor 20 Tahun 2003 tentang Sistem Pendidikan Nasional

VanPatten, B. (1996). Input Processing and Grammar Instruction in Second Language Acquisition. USA: Alex Publishing Corporation.

Yang, AL, \& Wang, PL Investigating the Relationship among Language Learning Strategies, English Self-Efficacy, and Explicit Strategy Instructions. Taiwan Journal of Tesol Vol. 12.1, 35-62. [On line]. Available: http://files.eric.ed.gov/fulltext/EJ1078937.pdf.

Zare, P. (2012). Language learning strategies among efl/esl learners: a review of the literature. International Journal of Humanities and Social 
Science Vol. 2 No. 5; March 2012 162. [Online]. Available: http://www. ijhssnet.com/ journals/Vol_2_No_5_March_2012/20.pdf.

Živković, S. (2014). The Importance of Oral Presentations For University Students. Mediterranean Journal of Social Sciences. Vol 5 No 19 August 2014. DOI:10.5901/mjss.2014.v5n19p468. [On line]. Available: http://www. mcser.org/ index.php/mjss/article/viewFile/4278/4184. pp 468-475. 